\title{
Adding fish images taken in other countries to the biodiversity database of a Japanese public museum, with report of range extension of Labrisomus jenkinsi from the Pacific coast of Costa Rica
}

Received: 3 June 2016/ Accepted: 22 October 2016/Published online: 1 November 2016

(C) The Ecological Society of Japan 2016

\begin{abstract}
Many biodiversity databases have been launched in recent years. Various species of certain developed taxa, such as fish, quadrupeds, and butterflies, are currently able to be photographically identified, in particular for ecological and biogeographic studies. However, there are problems that result from registration of images from countries with different primary languages. In this study, we provide an example of the challenges associated with registering fish images, specifically one case that has functioned as a voucher for the range extension of Labrisomus jenkinsi (Heller and Snodgrass, 1903) (Perciformes: Labrisomidae) from the Galapagos Islands to the Pacific coast of Costa Rica. The fish image database in question belongs to a Japanese public museum [the Kanagawa Prefectural Museum of Natural History; the online version (FishPix) is provided by the museum and the National Museum of Nature and Science]. We propose that there are problems associated with image registration caused by using different lan-
\end{abstract}

Y. Miyazaki $(\square)$

Shiraume Gakuen College, 1-830 Ogawa-chou, Kodaira, Tokyo 187-8570, Japan

E-mail: yukke-bibimba@10.alumni.u-tokyo.ac.jp

Tel.: + 81-42-346-5658

H. Senou $\cdot$ Y. Miyazaki

Kanagawa Prefectural Museum of Natural History, 499 Iryuda, Odawara, Kanagawa 250-0031, Japan

A. Murase

Nobeoka Marine Science Station, Faculty of Agriculture,

University of Miyazaki, 376-6 Akamizu, Nobeoka,

Miyazaki 889-0517, Japan

A. Murase

Department of Marine Biology and Environmental Sciences, Faculty of Agriculture, University of Miyazaki,

Gakuen-Kibanadai-Nishi, Miyazaki 889-2191, Japan

A. Murase

Parque Nacional Carara, Tárcoles, Garabito, Puntarenas 61102 , Costa Rica guages. Furthermore, these challenges should be a common subject for discussion among museums as they attempt to accumulate biodiversity data from citizens in the future.

Keywords Citizen science $\cdot$ Distribution $\cdot$ Documented record $\cdot$ Open science $\cdot$ Photograph

\section{Introduction}

Since 1992, many biodiversity online databases, such as the Global Biodiversity Information Facility (GBIF) and the Encyclopedia of Life (EOL), have been launched on a global scale, and their importance is increasing because of the growing realization of the urgency of biodiversity conservation worldwide (e.g., Novacek 2008; Devictor et al. 2010). Simultaneously, a new approach, citizen science, has been growing rapidly alongside the development of information and commu-

R. Sahara

Japan International Cooperation Agency (JICA) Costa Rica, Oficentro Ejecutivo del Mall San Pedro, 6to piso, San Pedro de Montes de Oca, San José 11501, Costa Rica

R. Sahara

Parque Nacional Manuel Antonio, Cantón de Aguirre, Puntarenas, Costa Rica

A. Angulo

Museo de Zoología, Universidad de Costa Rica, San Pedro de Montes de Oca, San José 11501-2060, Costa Rica

A. Angulo

Centro de Investigación en Ciencias del Mar y Limnologia (CIMAR), Universidad de Costa Rica, San Pedro de Montes de Oca, San José 11501-2060, Costa Rica

A. Angulo

Laboratório de Ictiologia, Departamento de Zoologia e Botânica, Universidade Estadual Paulista "Júlio de Mesquita Filho", Rua Cristóvão Colombo, São José do Rio Preto, SP 15054-000, Brazil 
nication technology (ICT), and creates new opportunities to monitor the natural environment and biodiversity over broad geographic regions (Kobori et al. 2016). Citizen science involves public participation and collaboration in scientific research to increase scientific knowledge (Kobori et al. 2016). Consequently, this approach constitutes a feasible method to collecting much broader scientific data that would otherwise be impossible to collect because of time and resource limitations, and has promoted notable advances in areas such as ecology, education, and conservation (Dickinson and Bonney 2012; Dickinson et al. 2012; Crain et al. 2014; Wals et al. 2014; Kobori et al. 2016).

Some ichthyology studies could also apply citizen science. In our focal example, fish museum collections, both specimens and photographs that include common and uncommon - even undescribed species - have been utilized in taxonomic and/or morphologic research, and in applied studies in areas such as macroecology, biogeography, and biodiversity conservation (see Miyazaki et al. 2014a, b, 2015a, b, 2016). Similarly, public participation in scientific programs that focus on fishes using ICT has been ongoing in some countries, mainly in the European Union and the United States (e.g., Silvertown et al. 2015; Wei et al. 2015), and it is currently expecting to spread worldwide (Silvertown 2009; Dickinson et al. 2010; Kano et al. 2013).

The Kanagawa Prefectural Museum of Natural History (KPM) in Japan has accumulated fish images from scientists and the general public as a museum collection since 1994, some of which are available online at the FishPix (Japanese: http://fishpix.kahaku.go.jp/fishimage/, English: http://fishpix.kahaku.go.jp/fishimage-e/). By February 2016, more than 170,000 fish images had been deposited into the collection, and a large portion of them are available online. These images have been used as a source of distributional data in taxonomical and biogeographical studies as vouchers for descriptions of body coloration and external morphological characters (see Matsuura and Senou 2002; Miyazaki et al. 2014b, 2015b), and enhancement of public awareness through lectures, exhibitions, guide books, and mass media (Miyazaki et al. 2014a, 2015a, 2016; Miyazaki 2015, 2016).

Most of the data in the fish image database are, of course, from Japan; roughly $86.7 \%$ of all images by February 2016, with the exception of those of aquarium origins, were from Japan. The remaining $13.3 \%$ were from 24 other countries and the open sea, i.e., Indonesia (approximately 5100 photos), Philippines (3900), Malaysia (2400), United States (1550), Fiji (1350), Costa Rica (1275), Palau (1250), and other countries $(<1000)$. Fish images from Costa Rica accounted for $0.8 \%$ of all images, which is the sixth-largest number of images for a country other than Japan. These images were mainly provided by AM (the second author) and RS (the third author), who were Japan Overseas Cooperation Volunteers members between January 2012 and March 2014 (AM), and from October 2014 (RS), working at Parque Nacional Carara (AM) and Parque Nacional Manuel
Antonio (RS). The images mostly correspond to specimens taken from the Pacific coast of the country.

The collection of Costa Rican fish images represent 162 species (including 11 unidentified species) from 58 families (Table 1). Some scientifically important

Table 1 Details of fish photographs taken in Costa Rica that were deposited into the Image Database of Kanagawa Prefectural $\mathrm{Mu}-$ seum of Natural History, Japan

\begin{tabular}{|c|c|}
\hline Family & No. of species \\
\hline Haemulidae & 17 \\
\hline Carangidae & 12 \\
\hline Pomacentridae & 9 \\
\hline Gerreidae & 7 \\
\hline Tetraodontidae & 7 \\
\hline Gobiidae & 6 \\
\hline Labridae & 6 \\
\hline Serranidae & 6 \\
\hline Centropomidae & 5 \\
\hline Eleotridae & 5 \\
\hline Lutjanidae & 5 \\
\hline Sciaenidae & 5 \\
\hline Ariidae & 4 \\
\hline Poeciliidae & 4 \\
\hline Acanthuridae & 3 \\
\hline Balistidae & 3 \\
\hline Batrachoididae & 3 \\
\hline Paralichthyidae & 3 \\
\hline Achiridae & 2 \\
\hline Belonidae & 2 \\
\hline Chaetodontidae & 2 \\
\hline Characidae & 2 \\
\hline Clupeidae & 2 \\
\hline Diodontidae & 2 \\
\hline Engraulidae & 2 \\
\hline Kyphosidae & 2 \\
\hline Mugilidae & 2 \\
\hline Muraenidae & 2 \\
\hline Polynemidae & 2 \\
\hline Pomacanthidae & 2 \\
\hline Scorpaenidae & 2 \\
\hline Albulidae & 1 \\
\hline Ateleopodidae & 1 \\
\hline Blenniidae & 1 \\
\hline Carcharhinidae & 1 \\
\hline Chaenopsidae & 1 \\
\hline Chlopsidae & 1 \\
\hline Cichlidae & 1 \\
\hline Cirrhitidae & 1 \\
\hline Dasyatidae & 1 \\
\hline Ephippidae & 1 \\
\hline Gobiesocidae & 1 \\
\hline Hemiramphidae & 1 \\
\hline Holocentridae & 1 \\
\hline Labrisomidae & 1 \\
\hline Lepisosteidae & 1 \\
\hline Lobotidae & 1 \\
\hline Moridae & 1 \\
\hline Muraenesocidae & 1 \\
\hline Ogcocephalidae & 1 \\
\hline Peristediidae & 1 \\
\hline Priacanthidae & 1 \\
\hline Scaridae & 1 \\
\hline Sparidae & 1 \\
\hline Syngnathidae & 1 \\
\hline Synodontidae & 1 \\
\hline Urolophidae & 1 \\
\hline
\end{tabular}


specimens and species are represented in this collection, which highlights the value of this kind of collection.

In this paper, we illustrate and discuss the case of the species Labrisomus jenkinsi (Heller and Snodgrass 1903) (Perciformes: Labrisomidae), which we herein report their occurrence in the Pacific coast of Costa Rica for the first time based on photographic evidence.

\section{Methods}

On 2 February 2013, a recreational fisherman (citizen), caught a fish specimen that belonged to family Labrisomidae at the mouth of the Mata de Limon River in Caldera, Esparza, Puntarenas, on the Pacific coast of Costa Rica. Although the fish was not preserved as a scientific specimen, because he ate it, several digital fullcolor photographs were taken (Fig. 1). The photographs supporting this record along with the attribute information were deposited into the fish image database of the KPM (original number: KPM-NR 141811), and were available online at the FishPix website after March 2016. The description of the specimen found in the next section was based on these photographs (Fig. 1: KPMNR 141811A-D).

\section{Description}

Dorsal-fin rays XVIII, 12 with the front spines not elongated, notched between spines and rays; anal-fin rays II, 17; pectoral-fin rays 14; head scaleless except for a few scales along top edge of gill cover. Fresh color of head brownish orange without pale spots, and fresh color of body greenish brown without pale spots, but with five diffuse blackish bars on the side and a subtle white streak at the mid-base of the caudal fin.

\section{Discussion}

The characteristics of the specimen photographed corresponded well to the color features of male Labrisomus jenkinsi, as described by Allen and Robertson (1994) and Robertson and Allen (2015). Although the external morphology of the specimen did not completely coincide with original descriptions - such as "six transverse bars," which was based on only three type specimens (Heller and Snodgrass 1903) - detailed ranges of the $L$. jenkinsi external morphology based on additional specimens were provided later, including "eight black bars extending onto dorsal fin" (Grove and Lavenberg 1997) or "5-6 diffuse blackish bars on side" (Allen and Robertson 1994; Robertson and Allen 2015). In addi-
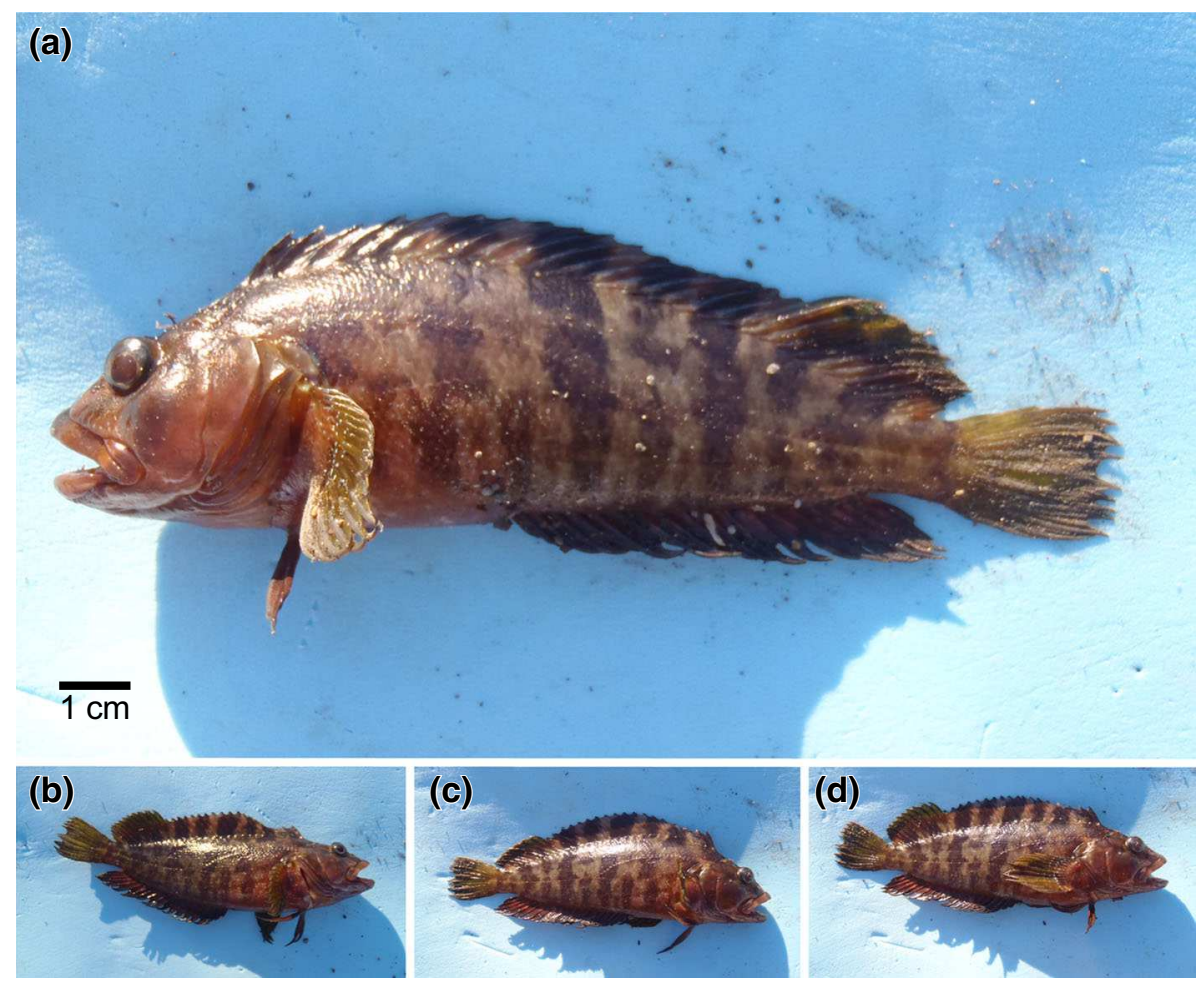

Fig. 1 Photographs of an individual of Labrisomus jenkinsi (Heller and Snodgrass 1903) captured from Caldera, Puntarenas on the Pacific coast of Costa Rica on 2 February 2013 (14.9 cm in total length; photo by AM). a The left side of the body (KPM-NR 141811B); b-d the right side of the body (KPM-NR 141811A, C, and D) 
tion, the number of dorsal-fin soft rays did not entirely coincide with the descriptions by Allen and Robertson (1994) and Robertson and Allen (2015), but it did correspond with the original description. This could be caused by geographic variation in the species. Thus, we identified the specimen photographed as L. jenkinsi.

Until now, no specimens of this species had been recorded in Costa Rican or Central American waters (Bussing and López 2009; Murase et al. 2014; Robertson and Allen 2015). This species has been known only from the Galapagos Islands (McCosker and Rosenblatt 2010; Robertson and Allen 2015). Only a related species, $L$. multiporosus, was recorded from central Baja California and the Gulf of California to Peru, and it is able to be distinguished from $L$. jenkinsi by its external color patterns, such as absence of five diffuse blackish bars on its side body, and presence of a pair of oblique brown bands across the cheek and an ocellus at the front of the dorsal fin (Robertson and Allen 2015). Therefore, this is the first known occurrence of $L$. jenkinsi in the Pacific coast of Costa Rica and Central America, with its subsequent range extension (approximately $700 \mathrm{~km}$ northeast), which is supported by photographic evidence along with associated attribute information. As demonstrated here, various species of developed taxa, such as fish, quadrupeds, and butterflies, are currently able to be photographically identified, particularly for ecological and biogeographic studies (e.g., Silvertown 2009, Silvertown et al. 2015; Kobori et al. 2016; Miyazaki 2016).

Unfortunately, the L. jenkinsi fish specimen was eaten. However, it is essential for supporting verifiable identification that citizen scientists keep the specimens and donate some local public museums. In Japan, the museums that belong to public boards of education (i.e. "registered museums") have a principle to permanently store their collections based on the National Museum Act (see Senou 2015 and the original sentences of the act and local ordinances related). Therefore, we recommend public museums for specimen donation.

Based on the present case, we propose an improvement in how data entry is performed when constructing these databases, and suggest that they should also account for multiple languages, contain more accurate attribute information (locality names, in particular), and that they should be more conveniently accessible to local citizens. Accounting for multiple languages would have greatly benefited researchers in this case, as the official language in most Latin American countries, including Costa Rica, is Spanish; because the KPM database is written and presented in Japanese and English, this will cause some conflicts from language differences. However, the curators are not familiar with languages other than English and Japanese. Additionally, specific accented characters (e.g., á, ñ, and ü in Spanish) are not available in the KPM database system. Therefore, accuracy of attribute information for scientific usage may not be guaranteed, especially for locality information, such as the correct name of the collection locality. We suspect that this is a topic common to all museums that attempt or will attempt to accumulate data from citizens.

Acknowledgements We deeply appreciate R. Takahashi, K. Horii, and K. Sodo for management of KPM collections, and K. Kase for generous help in Costa Rica. This study was partly supported by Grants-in-Aid (Numbers 22310143, 25 11038, and 16K16225) from the Ministry of Education, Culture, Sports, Science and Technology of Japan.

\section{References}

Allen GR, Robertson DR (1994) Fishes of the tropical eastern Pacific. Crawford House Press, Bathurst

Bussing WA, López M (2009) Marine fish. In: Wehrtman IS, Cortés J (eds) Marine biodiversity of Costa Rica, Central America. Springer Science + Business Media B.V, Dordrecht, pp 453-458

Crain R, Cooper C, Dickinson JL (2014) Citizen Science: a tool for integrating studies of human and natural systems. Annu Rev Environ Resour 39:641-665. doi:10.1146/annurev-environ030713-154609

Devictor V, Whittaker RJ, Beltrame C (2010) Beyond scarcity: citizen science programmes as useful tools for conservation biogeography. Diversity Distrib 16:354-362. doi:10.1111/ j.1472-4642.2009.00615.x

Dickinson JL, Bonney R (eds) (2012) Citizen Science: public participation in environmental research. Cornell University Press, Ithaca

Dickinson JL, Zuckerberg B, Bonter DN (2010) Citizen Science as an ecological research tool: challenges and benefits. Annu Rev Ecol Evol Syst 41:149-172. doi:10.1146/annurev-ecolsys102209-144636

Dickinson JL, Shirk J, Bonter D, Bonney R, Crain RL, Martin J, Phillips T, Purcell K (2012) The current state of citizen science as a tool for ecological research and public engagement. Front Ecol Environ 10:291-297. doi:10.1890/110236

Grove JS, Lavenberg RJ (1997) The fishes of the Galápagos Islands. Stanford University Press, Stanford

Heller E, Snodgrass RE (1903) Papers from the Hopkins Stanford Galapagos expedition, 1898-1899, XV, new fishes. Proc Wash Acad Sci 5:189-229, pls 2-20

Kano Y, Adnan MSB, Grudpan C, Grudpan J, Magtoon W, Musikasinthorn P, Natori Y, Ottomanski S, Praxaysonbath B, Phongsa K, Rangsiruji A, Shibukawa K, Shimatani Y, So N, Suvarnaraksha A, Thach P, Thanh PN, Tran DD, Utsugi K, Yamashita T (2013) An online database on freshwater fish diversity and distribution in Mainland Southeast Asia. Ichthyol Res 60:293-295. doi:10.1007/s10228-013-0349-8

Kobori H, Dickinson JL, Washitani I, Sakurai R, Amano T, Komatsu N, Kitamura W, Takagawa S, Koyama K, Ogawara T, Miller-Rushing AJ (2016) Citizen science: a new approach to advance ecology, education, and conservation. Ecol Res 31:1-19. doi:10.1007/s11284-015-1314-y

Matsuura K, Senou H (2002) Fish databases in Japan with special reference to fish-image database and its role in biodiversity study. Res Rep Natl Inst Environ Stud Jpn 171:220-227

McCosker JE, Rosenblatt RH (2010) The fishes of the Galápagos Archipelago: an update. Proc Calif Acad Sci 4th Ser 61(Suppl II): $167-195$

Miyazaki Y (2015) Putting biodiversity information on the Web to use scientifically for natural history. Newsl Kanagawa Prefect Mus Nat Hist 21:10-11

Miyazaki Y (2016) The relationship between Citizen Science and biodiversity information databases. Jpn J Ecol 66:237-246. doi: 10.18960/seitai.66.1 237

Miyazaki Y, Murase A, Senou H (2014a) Citizen participation in augmenting a museum database enhances fish monitoring and public awareness. J Aquat Mar Environ Edu Res 7:22-26 
Miyazaki Y, Murase A, Shiina M, Naoe K, Nakashiro R, Honda J, Yamaide J, Senou H (2014b) Biological monitoring by citizens using Web-based photographic databases of fishes. Biodivers Conserv 23:2383-2391. doi:10.1007/s10531-014-0724-4

Miyazaki Y, Murase A, Senou H (2015a) A natural history museum as a platform for accumulating verifiable information on non-native fishes: a Japanese example. Manag Biol Invasion 6:105-110. doi:10.3391/mbi.2015.6.1.08

Miyazaki Y, Murase A, Shiina M, Masui R, Senou H (2015b) Integrating and utilizing citizen biodiversity data on the Web for science: an example of a rare triggerfish hybrid image provided by a sport fisherman. J Coast Res 31:1035-1039. doi: 10.2112/JCOASTRES-D-14-00170.1

Miyazaki Y, Teramura A, Senou H (2016) Biodiversity data mining from Argus-eyed citizens: the first illegal introduction record of Lepomis macrochirus macrochirus Rafinesque, 1819 in Japan based on Twitter information. ZooKeys 569:123-133. doi: 10.3897/zookeys.569.7577

Murase A, Angulo A, Miyazaki Y, Bussing WA, López MI (2014) Marine and estuarine fish diversity in the inner Gulf of Nicoya, Pacific coast of Costa Rica, Central America. Check List 10:1401-1413. doi:10.15560/10.6.1401
Novacek MJ (2008) Engaging the public in biodiversity issues. Proc Natl Acad Sci USA 105:11571-11578. doi:10.1073/ pnas.0802599105

Robertson DR, Allen GR (2015) Shorefishes of the tropical eastern Pacific: online information system, version 2.0. http://biogeodb.stri.si.edu/sftep/en/pages. Accessed $25 \mathrm{Feb}$ 2016

Senou H (2015) What should we do in order to inherit natural history collections to future generations? Trends Sci 20(5):30-34. doi:10.5363/tits.20.5 30

Silvertown J (2009) A new dawn for citizen science. Trends Ecol Evol 24:467-471. doi:10.1016/j.tree.2009.03.017

Silvertown J, Harvey M, Greenwood R, Dodd M, Rosewell J, Rebelo T, Ansine J, McConway K (2015) Crowdsourcing the identification of organisms: a case-study of iSpot. Zookeys 480:125-146. doi:10.3897/zookeys.480.8803

Wals AEJ, Brody M, Dillon J, Stevenson RB (2014) Convergence between science and environmental education. Science 344:583-584. doi:10.1126/science. 1250515

Wei J, Stiem T, Pollom R (2015) iSeahorse: seahorse conservation through citizen science. Reef Encounter 30:40-42 